\title{
Urinary Albumin Excretion and Severity of Coronary Artery Disease by Coronary Angiography in Patients with Type 2 Diabetes
}

\author{
ELHAM O. HAMED, M.D.*; AHMED M. BOGHDADY, M.D.**; HASSAN A.H. SHEHATA, M.D.** and \\ ALAA A. GHALEB, M.Sc.** \\ The Departments of Clinical Pathology* and InternalMedicine**, Faculty of Medicine, Sohag University, Sohag, Egypt
}

\begin{abstract}
Background: Coronary Artery Disease (CAD) is a major cause of death in developed and developing countries. Many of CAD patients don't have any other classic risk factor except diabetes. The aim of this study was to investigate the relationship between urinary albumin excretion and severity of coronary artery lesion by coronary angiography in type 2 diabetic patients.
\end{abstract}

Patients and Methods: This study, conducted with 200 type 2 diabetic patients with documented CAD by coronary angiography. The ratio of urinary albumin to creatinine was calculated. The study populations were classified according to albumin to creatinine ratio, Group I: Normoalbuminuric group (120 diabetic patients), Group II (80 patients) and subdivided into Group II a (56 microalbuminuria patients), Group II b (24 macroalbuminuria patients). The severity of CAD was estimated using multi-vessel affection and SYNTAX score.

Results: The prevalence of triple vessel CAD was significantly higher in Group II (microalbuminuic and macroalbuminuric patients). Triple vessel CAD was present in $13.3 \%$ of patients in Group I (normoalbuminuric), whereas it was present in $62.5 \%$ of patients in Group II $(p<0.001)$. Left main artery stenosis was present in $8.3 \%$ in Group I and $20 \%$ in Group II $(p=0.03)$. Of patients, $16.6 \%$ and $70 \%$ in Group I and II had Ostial and Para ostial stenosis respectively $(p<0.001)$. Major side branch stenosis was present in $20 \%$ of patients in Group I and in $90 \%$ of patients Group II $(p<0.001)$ The severity of CAD by SYNTAX score revealed that, patients of Group II had higher SYNTAX scores compared to Group I ( $29 \pm 8$ vs. $\left.16_{-3} 6, p<0.001\right)$. Patients with macroalbuminuria had higher SYNTAX scores compared to those with microalbuminuria ( $30 \pm 3$ vs. $26_{-}, 6, p=0.001$ ). Multivariate logistic regression analysis found smoking, dyslipidemia and albuminuria were risk factors for coronary artery lesion ( $p=0.004$ $p<0.001$ and $p<0.01$ respectively).

Conclusion: Patients with microalbuminuria and macroalbuminuria have more extensive and severe angiographic CAD compared to those with normoalbuminuria.

Correspondence to: Dr. Elham O. Hamed, The Department of Clinical Pathology, Faculty of Medicine, Sohag University, Sohag, Egypt
Key Words: Coronary artery disease-SYNTAX score-Type 2 diabetes mellitus.

\section{Introduction}

DIABETES Mellitus (DM) is a chronic metabolic disease has many complications; prevalence of these complications is increasing [1]. Cardiovascular disease is the most important one of these patients [2] . Coronary Artery Disease (CAD) is a major cause of death in developed and developing countries. Advancing age, male sex, hypertension, diabetes mellitus, dyslipidemia and cigarette smoking are the independent risk factors for CAD [3]. Many of CAD patients don't have any other risk factors except diabetes [4], thus many researchers are trying to find new risk factors to identify patients potentially at risk for CAD. Urinary Albumin Excretion (UAE) is a marker of endothelial and vascular damage which could be a predictor for coronary artery atherosclerosis $[\mathbf{5 , 6 ]}$ independent of renal function [7]. The term microalbuminuria is defined as urinary albumin levels of more than or equal to $30-300 \mathrm{mg} / 24 \mathrm{~h}$ in $24-\mathrm{h}$ urine collection or Albumin/ Creatinine ratio (A/C) of $30-300 \mathrm{mg} / \mathrm{g}$ creatinine in the random spot urine sample. Macroalbuminuria is defined as urinary albumin levels of more than $300 \mathrm{mg} / 24 \mathrm{~h}$ or Albumin/Creatinine ratio (A/C) $>300$ $\mathrm{mg} / \mathrm{g}$ creatinine. How UAE may be related to the development of atherosclerotic disease is unclear. The most accepted explanation that UAE causes local injury of vascular smooth muscle cells and endothelium leading to cell proliferation and increase in vascular permeability $[\mathbf{8 , 9}$. It is also reported that patients with UAE have a greater atherosclerosis burden. This study aimed to investigate the relationship between Urinary Albumin excretion and severity of coronary artery lesion by coronary angiography in type 2 diabetic patients. 


\section{Patients and Methods}

A case control study, we evaluated 200 type 2 diabetic patients, according to American Diabetes Association criteria [10]. They underwent coronary angiography as a part of the clinical work-up for symptoms or signs of heart disease and documented as coronary artery disease by coronary angiography at the Sohag University Hospital from April 2014 to March 2015. Inclusion criteria: Patients with type 2 diabetes mellitus and documented coronary artery disease by coronary angiography. The exclusion criteria: Urinary tract infection, hematuria, chronic kidney disease, congestive heart failure and acute coronary syndrome. The study populations were classified according to albumin to creatinine ratio (A/C ratio) into Group I: Normoalbuminuric group (120 diabetic patients (A/C ratio $<30 \mathrm{mg} / \mathrm{g}$ ), Group II (80 patients with A/C ratio $30 \mathrm{mg} / \mathrm{g}$ ) and subdivided into Group II a (56 microalbuminuria patients A/C ratio $30-300 \mathrm{mg} / \mathrm{g}$ ), Group II b (24 macroalbuminuria patients $\mathrm{A} / \mathrm{C}$ ratio $>300 \mathrm{mg} / \mathrm{g}$ ). In addition to 20 age and sex matched healthy individuals as a control group. Informed written consent was obtained from each individual before participation. The study was approved by the Ethics Committee of Sohag Faculty of Medicine. For all individuals medical history and clinical examination were recorded.

Venous blood sample was collected from all study participants after 12 hours of fasting, for laboratory analysis. The first voided urine sample was collected for $\mathrm{A} / \mathrm{C}$ ratio measurement and urine analysis. Whole blood in EDTA coated tubes used for complete blood picture and glycosylated hemoglobin $\left(\mathrm{HbA}_{1 \mathrm{c}}\right)$. Serum glucose, lipid profile, A/C ratio, liver function tests and serum and urine creatinine were determined by autoanalyzer Cobas c 311 (Roche/Hitachi cobas c systems). Blood picture was performed on Cell Dyne 1700 Abbott diagnostics (USA). $\mathrm{HbA}_{1 \mathrm{c}}$ was determined by ionexchange High-Performance Liquid Chromatography (HPLC) (The BioRad D 10 analyser). Urine creatinine concentration was based on the kinetic Jaffe method according to the manufacturer's instructions. Albumin in urine based on Immunoturbidimetric assay, antigen in the sample reacts with anti-albumin antibodies form antigen/antibody complexes which measured turbidimetrically. Albumin/creatinine ratio was calculated, it is the ratio of urinary albumin to urinary creatinine; usually it is expressed as milligram of albumin excreted per gram of urinary creatinine.

$$
\mathrm{A} / \mathrm{C}(\mathrm{mg} / \mathrm{g})=\begin{gathered}
\text { Albumin }(\mathrm{mg} / \mathrm{dl}) \\
\text { Creatinine }(\mathrm{mg} / \mathrm{dl})
\end{gathered} \quad \mathrm{X} 1000
$$

ECG and echocardiography: Trans-thorathic Echo for detection of segmental wall motion abnormalities, categorization of Wall Motion Score Index (WMSI): The left ventricular wall was divided into 16 segments and scored using a 4-point scale: $1=$ normal, $2=$ hypokinetic, $3=$ akinetic, $4=$ dyskinetic.

- A Wall Motion Score Index (WMSI) calculated by adding the numeric value assigned to each segment and dividing by the number of visualized segments.

Angiographic data: Selective coronary angiography was performed in all patients under local anesthesia via the femoral artery using the Judkins technique. The severity of each lesion was assessed by quantitative coronary angiography. The presence and total severity of CAD was assessed according to the Syntax scoring system m] . The SYNTAX score calculator is available directly online or it was downloaded directly to a computer. To obtain correct scoring results, we did it with a team of three people, and consequently discussing the score resulting. Left and right coronary vasculatures were assessed. Each significant coronary lesion was defined as at least $50 \%$ diameter stenosis with at least $1.5 \mathrm{~mm}$. Lesion location is described using coronary tree segments. After each lesion is scored, the individual lesion scores will be automatically summed, and the patient's overall SYNTAX score will be calculated as follows:

1 - Low $\leq 22$.

2- Intermediate 23-32.

3- High ( $\geq 33$ ).

\section{Statistical analysis:}

Data was analyzed using STATA intercooled Version 12. 1. Quantitative data was represented as mean, standard deviation and median. Data was analyzed using student $t$-test to compare means of two groups and ANOVA for comparison of the means of three groups or more. When the data was not normally distributed Kruskal Wallis test for comparison of three groups and Mann-Whitney test was used to compare two groups. Qualitative data was presented as number and percentage and compared using either Chi square test or fisher exact test. Univariate and multivariate linear regression to determine the factors that affect Syntax score. $p$-value was considered significant if it was $<0.05$.

\section{Results}

Clinical characteristics and laboratory variables of the all studied groups were demonstrated in 
(Table 1). Serum glucose, lipogram and $\mathrm{HbA}_{1 \mathrm{c}}$ levels were significantly higher in diabetic patients than control group ( $p<0.01$ for each). Demographic and clinical features of the Group I and Group II were demonstrated in (Table 2). There was no significant difference regarding age, sex, smoking, history of CAD and s.creatinine between the two groups. There was significant difference as regard dyslipidemia, $\mathrm{HgA}_{1 \mathrm{c}}$, signs of CHD by ECG and Echo in Group II. The distribution of CAD severity as the regard multi vessel disease in the groups with and without albuminuria is presented in (Table 3). The prevalence of triple vessel CAD was significantly higher in Group II. Triple vessel CAD was present in $13.3 \%$ of patients in Group I, whereas it was present in $62.5 \%$ of patients in Group II $(p<0.001)$. Left main artery stenosis was present in $8.3 \%$ in Group I and $20 \%$ in Group II ( $p=0.03)$. Of patients, $16.6 \%$ and $70 \%$ in Group I and II had Ostial \& Para ostial stenosis respectively $(p<0.001)$. Major side branch stenosis was present in $20 \%$ of patients in Group I and in $90 \%$ of patients Group II $(p<0.001)$. There was statistically significant

Table (1): Clinical characteristics and laboratory variables of studied population.

\begin{tabular}{|c|c|c|c|}
\hline Feature & $\begin{array}{l}\text { Patients } \\
(n=200)\end{array}$ & $\begin{array}{l}\text { Controls } \\
(n=200)\end{array}$ & $\begin{array}{c}p- \\
\text { value }\end{array}$ \\
\hline Age/years & $58.16 \pm 8.95$ & $52.7 \pm 6.7$ & - \\
\hline $\begin{array}{l}\text { Gender: } \\
\text { Males } \\
\text { Females }\end{array}$ & $\begin{array}{l}106(53 \%) \\
94(47 \%)\end{array}$ & $\begin{array}{l}13(65 \%) \\
7 \quad(35 \%)\end{array}$ & - \\
\hline Smoking & $90(45 \%)$ & - & - \\
\hline History of CAD & $64(32 \%)$ & - & - \\
\hline Duration of DM in years & $10.24 \pm 5.17$ & - & - \\
\hline Total cholesterol mg/dl & $220 \pm 6.1$ & $150 \pm 9.4$ & $<0.01$ \\
\hline Triglyceride mg/dl & $230 \pm 8.2$ & $124 \pm 3.1$ & $<0.01$ \\
\hline HDL mg/dl & $38 \pm 1.2$ & $45 \pm 3.8$ & $<0.01$ \\
\hline LDL mg/dl & $122 \pm 5.1$ & $85 \pm 11.2$ & $<0.01$ \\
\hline VLDL mg/dl & $48 \pm 2.1$ & $25 \pm 3.2$ & $<0.01$ \\
\hline S. glucose $\mathrm{mg} / \mathrm{dl}$ & $215.1 \pm 30.5$ & $85.2 \pm 23$ & $<0.01$ \\
\hline $\mathrm{HbA} 1 \mathrm{c} \%$ & $8.9 \pm 2.4$ & $5.2 \pm 1.1$ & $<0.01$ \\
\hline Serum creatinine $\mathrm{mg} / \mathrm{dl}$ & $0.98 \pm 0.18$ & $0.9 \pm 1.3$ & $>0.05$ \\
\hline $\begin{array}{l}A / C \mathrm{mg} / \mathrm{g}: \\
\text { Normoalbuminuria } \\
\text { Microalbuminuria } \\
\text { Macroalbuminuria }\end{array}$ & $\begin{array}{l}120(60 \%) \\
56(28 \%) \\
24(12 \%)\end{array}$ & $\begin{array}{c}20(100 \%) \\
- \\
-\end{array}$ & $\begin{array}{l}>0.05 \\
<0.01 \\
<0.01\end{array}$ \\
\hline
\end{tabular}

Table (3): Coronary angiography features of patients group.

\begin{tabular}{llll}
\hline Feature & $\begin{array}{c}\text { Group I } \\
(\mathrm{n}=120)\end{array}$ & $\begin{array}{c}\text { Group II } \\
(\mathrm{n}=80)\end{array}$ & $\begin{array}{c}p- \\
\text { value }\end{array}$ \\
\hline $\begin{array}{llll}\text { Number of vessels: } \\
1\end{array}$ & $72(60.67 \%)$ & $10(12.5 \%)$ & $<0.001$ \\
2 & $32(26.67 \%)$ & $20(25 \%)$ & $>0.05$ \\
3 & $16(13.33 \%)$ & $50(62.5 \%)$ & $<0.001$ \\
Left main artery stenosis & $10(8.3 \%)$ & $16(20 \%)$ & 0.03 \\
Ostial \& Para ostial stenosis & $20(16.6 \%)$ & $56(70 \%)$ & $<0.001$ \\
Major side branch stenosis & $24(20 \%)$ & $72(90 \%)$ & $<0.001$ \\
\hline
\end{tabular}

difference between patients with and those without albuminuria regarding their SYNTAX scores. Patients of Group II had higher SYNTAX scores compared to Group I ( $29 \pm 8$ vs. $16 \pm 6, p<0.001$ ), as shown in (Table 4). In both groups, the severity of CAD by SYNTAX score was evaluated, in Group I, 60 patients $(50 \%)$ had a low SYNTAX score, 40 patients $(33.3 \%)$ had an intermediate and 20 patients $(16.7 \%)$ had high scores. In Group II, 20 patients $(25 \%)$ had a low SYNTAX score and 24 patients (30\%) had an intermediate and 36 patients (45\%) had high scores. Patients with macroalbuminuria had higher SYNTAX scores compared to those with microalbuminuria ( $30 \pm 3$ vs. $26 \pm 6, p=$ 0.001) (Table 5), Fig. (1). Multivariate logistic regression analysis was performed to assess the effect of age, gender, smoking, history of CAD, duration of DM, dyslipidemia, control of DM and albuminuria on coronary artery lesion (Table 6). We found smoking, dyslipidemia and albuminuria were risk factors for coronary artery lesion $(p=$ $0.004, p<0.001$ and $p<0.01$ respectively).

Table (2): Demographic and clinical features of patients groups.

\begin{tabular}{llll}
\hline Feature & $\begin{array}{c}\text { Group I } \\
(\mathrm{n}=120)\end{array}$ & $\begin{array}{c}\text { Group II } \\
(\mathrm{n}=80)\end{array}$ & $\begin{array}{c}p \text { - } \\
\text { value }\end{array}$ \\
\hline $\begin{array}{l}\text { Age/years } \\
\text { Gender: }\end{array} \quad 59.2 \pm 7.13$ & $56.6 \pm 11.06$ & 0.06 \\
$\quad$ Males & $56(46.67 \%)$ & $50(62.50 \%)$ & 0.12 \\
$\quad$ Females & $64(53.33 \%)$ & $30(37.50 \%)$ & \\
Smoking & $45(37.5 \%)$ & $45(56 \%)$ & 0.11 \\
History of CAD & $32(26.67 \%)$ & $32(40 \%)$ & 0.07 \\
Duration of DM in years & $10.5 \pm 4.2$ & $14.5 \pm 3.7$ & $<0.01$ \\
Dyslipidemia & $90(75 \%)$ & $70(87 \%)$ & 0.04 \\
HgA1c $>7 \%$ & $80(66.7 \%)$ & $60(75 \%)$ & 0.03 \\
Serum creatinine mg/dl & $0.98 \pm 0.18$ & $0.99 \pm 0.20$ & 0.72 \\
ECG Ischemic & $64(53.33 \%)$ & $64(80 \%)$ & 0.001 \\
Echo (WMSI): & & & \\
$\quad 1-1.4$ & $90(75 \%)$ & $45(56 \%)$ & 0.02 \\
$1.5-1.9$ & $20(16.6 \%)$ & $18(22.5 \%)$ & \\
$2 .-2.4$ & $8(6.6 \%)$ & $12(15 \%)$ & \\
$2.5-3$ & $2(1.6 \%)$ & $5(6.5 \%)$ & \\
\hline
\end{tabular}

Table (4): Syntax score of patients group.

\begin{tabular}{llll}
\hline Feature & $\begin{array}{c}\text { Group I } \\
(\mathrm{n}=120)\end{array}$ & $\begin{array}{c}\text { Group II } \\
(\mathrm{n}=80)\end{array}$ & $\begin{array}{c}p- \\
\text { value }\end{array}$ \\
\hline $\begin{array}{l}\text { Syntax score: } \\
\quad \text { Median } \pm \mathrm{IQR}\end{array}$ & $16 \pm 6$ & $29 \pm 8$ & $<0.001$ \\
$\quad$ & & \\
Syntax score: & & & \\
$\quad$ Low & $60(50 \%)$ & $20(25 \%)$ & $<0.001$ \\
$\quad$ Intermediate & $40(33.3 \%)$ & $24(30 \%)$ & $>0.05$ \\
$\quad$ High & $20(16.7 \%)$ & $36(45 \%)$ & $<0.001$ \\
\hline
\end{tabular}


Table (5): Syntax score of studied patients according to the degree of albuminuria.

\begin{tabular}{lllll}
\hline Feature & $\begin{array}{c}\text { Group I } \\
(\mathrm{N}=120)\end{array}$ & $\begin{array}{c}\text { Group II a } \\
(\mathrm{N}=56)\end{array}$ & $\begin{array}{c}\text { Group II b } \\
(\mathrm{N}=24)\end{array}$ & $\begin{array}{c}p \text { - } \\
\text { value }\end{array}$ \\
\hline $\begin{array}{l}\text { Syntax score: } \\
\quad \text { Median } \pm \mathrm{IQR}\end{array}$ & $16 \pm 6$ & $26 \pm 6$ & $30 \pm 3$ & 0.001 \\
$\quad \begin{array}{lllll}\text { Syntax score: } \\
\quad \text { Low }\end{array}$ & $60(50 \%)$ & $16(29 \%)$ & $4(16 \%)$ & 0.002 \\
$\quad$ Intermediate & $40(33.3 \%)$ & $18(32 \%)$ & $6(25 \%)$ & 0.06 \\
$\quad$ High & $20(16.7 \%)$ & $22(39 \%)$ & $14(59 \%)$ & 0.002 \\
\hline
\end{tabular}

Table (6): Multivariate linear regression analysis of several risk factors affecting coronary heart diseases.

\begin{tabular}{lll}
\hline Feature & $\begin{array}{c}\text { Regression co-efficient } \\
(95 \% \text { Confidence interval) }\end{array}$ & $p$-value \\
\hline Age/years & $0.08(-0.003: 0.16)$ & 0.16 \\
Males vs. females & $5.23(3.64: 6.82)$ & 0.12 \\
Smoking & $6.15(4.20: 8.10)$ & 0.004 \\
History of CAD & $3.84(1.84: 8.09)$ & 0.16 \\
Duration of DM & $0.88(-0.04: 1.79)$ & 0.06 \\
Dyslipidemia & $4.94(2.97: 6.91 \%)$ & $<0.001$ \\
HgA1 c >7\% vs. $<7 \%$ & $-0.41(-2.63: 1.82)$ & 0.052 \\
Serum creatinine & $-0.79(-6.07: 4.50)$ & 0.79 \\
A/C ratio: & & $<0.01$ \\
$\quad$ Group (I) vs (IIa) & $13.96(9.44-18.47)$ & $<0.01$ \\
$\quad$ Group (I) vs (IIb) & $24.57(20.47: 28.45)$ & $<0.01$ \\
\hline Group (IIa) vs (IIb) & $20.6(16.5: 24.5)$ & \\
\hline
\end{tabular}

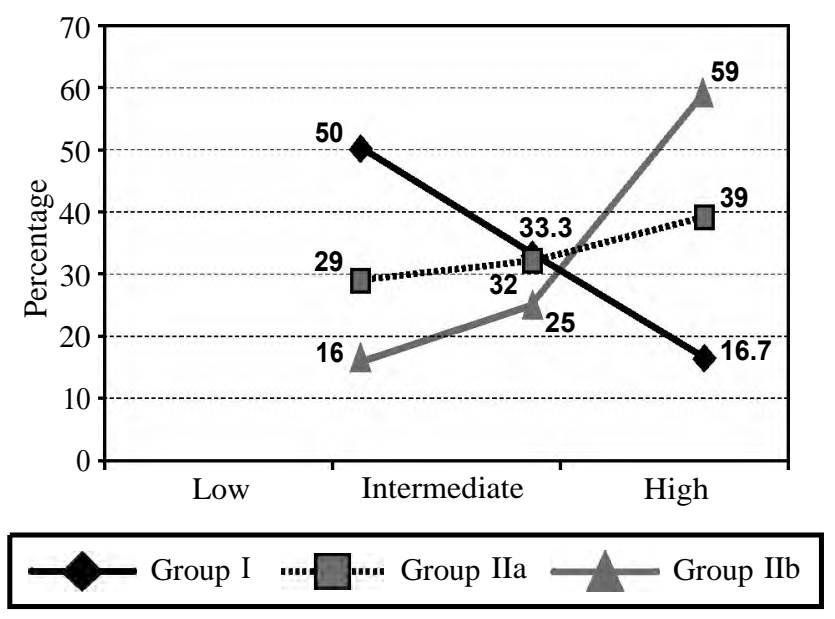

Fig. (1): Syntax score of studied patients according to the degree of albuminuria.

\section{Discussion}

Albuminuria had long been known as a major risk factor for renal disease, but also it is highly prevalent in several disease states. In this study, we found that the frequency of microalbuminuria and macroalbuminuria was elevated in the our study population (40\%) which is significantly higher as compared to the other general population studies which ranges from $5 \%$ to $7 \%[12,13]$. Thus, this study highlights that micro and macro is more frequent in patients with CAD than the general population and may be an important emerging risk marker for CAD. In the present study, there were significant differences in the prevalence of dyslipidemia, HBA1C, duration of diabetes and ECG changes and Echo of CAD between the two groups. Gou et al., [14] found significant differences between microalbuminuria with duration of diabetes mellitus, HbA1C, FPG, LDL-C, HDL-C. All of these factors contribute to the occurrence of atherosclerosis.

The study showed that patients with microalbuminuria and macroalbuminuria have a greater atherosclerotic burden and a more severe CAD in the form of total number of vessels affected per patient than those with normoalbuminuria. The prevalence of triple vessel CAD was significantly higher in Group II $(p<0.001)$. Group II had more complex stenosis, left main artery stenosis $(20 \%)$ major side branches stenosis $(90 \%)$, ostial and paraostial stenosis $(70 \%)$. The results are in accordance with the previously reported findings [15-18] . Rein et al., [19] found that the prevalence of stenoses of $\geq 50 \%$ was significantly greater in patients with albuminuria than in those with normoalbuminuria ( $66 \%$ vs $51 \%$; $p<0.001)$. Khan et al., [20] who found that patients with microalbuminuria have more severe angiographically detected coronary artery disease than those without microalbuminuria, thus a link can be established independent of other risk factors.

In the present study, patients with microalbuminuria and macroalbuminuria had higher SYNTAX scores compared to those with normoalbuminuria $(29 \pm 8$ vs. $16 \pm 6, p<0.001)$ and patients with macroalbuminuria had higher SYNTAX scores compared to those with microalbuminuria ( $30 \pm 3$ vs. $26 \pm 6, p=0.001$ ), showing that the presence of macroalbuminuria was associated with more complex CAD. These findings were in agreement with previous reports who found that patients with microalbuminuria have more severe angiographies CAD than those without microalbuminuria $[15,21]$ In Multivariate logistic regression analysis,we found smoking, dyslipidemia and albuminuria were risk factors for coronary artery lesion $(p=0.004, p$ $<0.001$ and $p<0.01$ respectively). Long-term lipid abnormalities and smoking in patients with diabetes result in vascular damage and endothelial dysfunction. Albuminuria considered as an emerging cardiovascular risk factor in diabetic patients. The mechanism whereby albuminuria accelerates atherosclerosis is unclear, may be alterations in the extracellular matrix cause an increase in vas- 
cular permeability and this contributes to the development of endothelial dysfunction, which promotes lipid influx into the vessel wall causing atherosclerotic changes [22]. Moreover another study found that albuminuria could predict cardiac autonomic imbalance in patients with nonobstructive CAD evaluated by Heart rate recovery [23]. So it appears that aggressive treatment of albuminuria is beneficial in CAD patients.

\section{Conclusion:}

Patients with microalbuminuria and macroalbuminuria have more extensive and severe angiographies CAD compared to those with normoalbuminuria, and the presence of macroalbuminuria was associated with more complex CAD. The implementation of this simple assay in clinical routine may influence the aggressiveness of management and ultimately the outcome of the disease.

\section{References}

1- WILD S., ROGLIC G., GREEN A., SICREE R. and KING H.: Global prevalence of diabetes: Estimates for the year 2000 and projections for 2030. Diabetes Care, 27 (5): 1047-53, 2004.

2- PANZRAM G.: Mortality and survival in Type 2 (noninsulin dependent) diabetes mellitus. Diabetologia, 30 (3): 123-31, 1987.

3- KUULASMAA K., TUNSTALL-PEDOE H., DOBSON A., FORTMANN S., SANS S., TOLONEN H., EVANS A., et al.: Estimation of contribution of changes in classic risk factors to trends in coronary-event rates across the WHO MONICA Project populations. Lancet, 355 (9205): 675-87, 2000.

4- PAHOR M., ELAM M.B., GARRISON R.J., KRITHEVSKY S.B. and APPLEGATE W.B.: Emerging noninvasive biochemical measures to predict cardiovascular risk. Archives of Internal Medicine, 159 (3): 237 45, 1999.

5- STEHOUWER C.D., HENRY R.M., DEKKER J.M., NIJPELS G., HEINE R.J. and BOUTER L.M.: Microalbuminuria is associated with impaired brachial artery, flow-mediated vasodilation in elderly individuals without and with diabetes: Further evidence for a link between microalbuminuria and endothelial dysfunction-The Hoorn Study. Kidney Int. Suppl., (92): S42-4, 2004.

6- QUYYUMI A.A.: Prognostic value of endothelial function. Am. J. Cardiol., 91 (12A): 19H-24H, 2003.

7- ADLER A.I., BOYKO E.J., AHRONI J.H. and SMITH D.G.: Lowerextremity amputation in diabetes. The independent effects of peripheral vascular disease, sensory neuropathy, and foot ulcers. Diabetes Care, 22 (7): 102935, 1999.

8- TADDEI S., VIRDIS A., MATTEI P., GHIADONI L., SUDANO I., ARRIGHI P. and SALVETTI A.: Lack of correlation between microalbuminuria and endothelial function in essential hypertensive patients. J. Hypertens, 13 (9): 1003-8, 1995.
9- BAKRIS G.C., RANDALL O., RAHMAN M., et al.: For the African American Study of Kidney Disease (AASK) Study Group. Association between cardiovascular risk factors and glomerular filtration rate at baseline in the AASK trial. J. Am. Soc. Nephrol., 9: 139, 1998.

10- American Diabetes Association: Diagnosis and classification of diabetes mellitus. Diabetes Care, 33 (4): e57, 2010.

11- SIANOS G., MOREL M.A., KAPPETEIN A.P., MORICE M.C., COLOMBO A., DAWKINS K., VAN DEN BRAND M., VAN DYCK N., RUSSELL M.E., MOHR F.W. and SERRUYS P.W. : The SYNTAX Score: An angiographic tool grading the complexity of coronary artery disease. Euro. Intervention, 1 (2): 219-27, 2005.

12- ATKINS R.C. : The epidemiology of chronic kidney disease. Kidney Int. Suppl., 94: S14-18, 2005.

13- HILLEGE H.L., JANSSEN W.M., BAK A.A., DIERCKS G.F., GROBBEE D.E., CRIJNS H.J., VAN GILST W.H., et al.: Microalbuminuria is common, also in a nondiabetic, nonhypertensive population, and an independent indicator of cardiovascular risk factors and cardiovascular morbidity. J. Intern. Med., 249 (6): 519-26, 2001.

14- GUO L., CHENG Y., WANG X., PAN Q., LI H, ZHANG L. and WANG Y.: Association between microalbuminuria and cardiovascular disease in type 2 diabetes mellitus of the Beijing Han nationality. Acta Diabetol., (Suppl 1): S65-71, 2012.

15- SUKHIJA R., ARONOW W.S., KAKAR P., GARZA L., SACHDEVA R., SINHA A. and MEHTA J.L. : Relation of microalbuminuria and coronary artery disease in patients with and without diabetes mellitus. Am. J. Cardiol., 98 (3): 279-81, 2006.

16- HASHIM R., NISAR S., URREHMAN K., et al.: Microalbuminuria: Association with ischemic heart disease in non-diabetics. J. Ayub. Med. Coll. Abbottabad., 18 (1): 40-3, 2006.

17- HOSEINI V.N. and RASOULI M.: Microalbuminuria correlates with the prevalence and severity of coronary artery disease in non-diabetic patients. Cardiol. J., 16 (2): 142-5, 2009.

1 8- AL-SAFFAR H.B., NASSIR H., MITCHELL A. and PHILIPP S.: Microalbuminuria in non-diabetic patients with unstable angina/non ST-segment elevation myocardial infarction. B.M.C. Res. Notes, 8: 3 71, 2015.

19- REIN P., VONBANK A., SAELY C.H., BEER S., JANKOVIC V., BOEHNEL C., BREUSS J., RISCH L., FRAUNBERGER P. and DREXEL H.: Relation of albuminuria to angiographically determined coronary arterial narrowing in patientswith and without type 2 diabetes mellitus and stable or suspected coronary artery disease. Am. J. Cardiol., 15; 107 (8): 1144-8, 2011.

20- KHAN K.N., KHAN M.H. and HAQUE M.Z.: Correlation between microalbuminuria with complexity of coronary artery disease in diabetic patients. Mymensingh. Med. J., 22 (2): 353-7, 2013.

21- LEKATSAS I., KRANIDIS A., IOANNIDIS G., KALOFOUTIS C., TAVERNARAKIS A., THALASSINOS N., KALOFOUTIS A., et al.: Comparison of the extent and severity of coronary artery disease in patients with acute myocardial infarction with and without microalbuminuria. Am. J. Cardiol., 94 (3): 334-7, 2004. 
22- SCHMITZ A.: Microalbuminuria, blood pressure, metabolic control, and renal involvement: longitudinal studies in white non-insulin-dependent diabetic patients. Am. J. Hypertens, 10 (9 Pt 2): 189S-197S, 1997.
23- YURTDAS M., OZDEMIR M., ALADAG N. and YAYLALI Y.T.: Association of heart rate recovery with microalbuminuria in non-obstructive coronary artery disease. Cardiol. Res., 8 (5): 206-13, 2017.

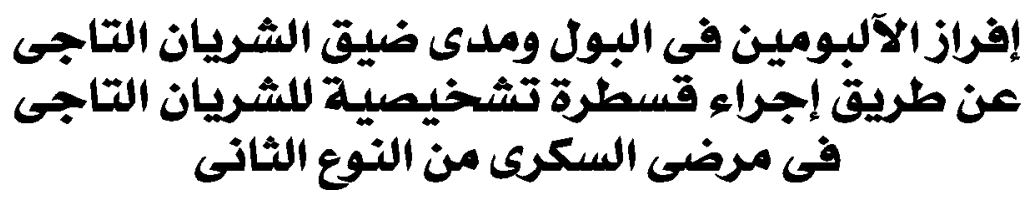

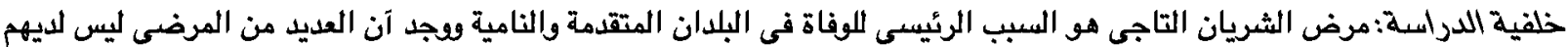

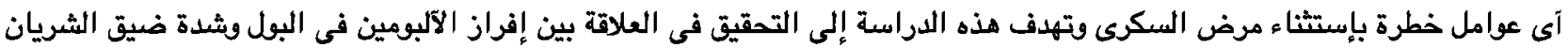

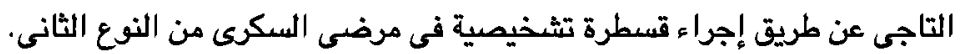

الآفراد وطرق البحث: آجريت الدراسة على · . r مريض من مرضى السكرى من النوع الثانى الذين ثبت لديهم ضيق بالشرايين التاجية

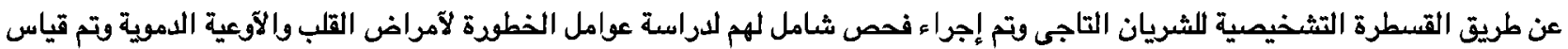
نسبة الآلبومين إلى الكرياتينين في البول وتم تقييم نسبة الضيق في الشريان التاجى بإستخدام SYNTAX score.

النتائج: .1 مريض لديهم آلبومين فى البول، ع لهريض لديهم تاريخ مرضى بجلطة فى الشريان التاجى اللقلب وقد تبين وجود ضيق بشريان

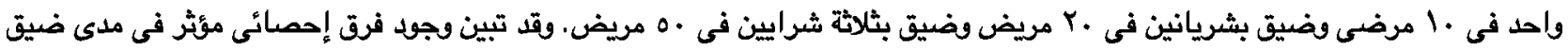

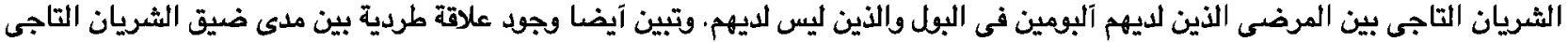
ونسبة إفراز الآلبومين.

النتائج: آثبتت نتائج هذه الرسالة آن الآلبومين البولى (مستقلا بذاته) يعتبر من عوامل الخطوة لآمراض القلب والآوعية الدموية. 